\title{
Towards a conceptual model for assessing the quality of public services
}

\author{
Cláudia Carvalho \& Carlos Brito \& \\ José Sarsfield Cabral
}

\begin{abstract}
The aim of this paper is to contribute to a better understanding of the determinants of public service quality. Firstly, it explores the relationships that develop during the public service encounter between the citizen, the public organization and society. Secondly, citizen satisfaction and dissatisfaction with public services are both investigated. Furthermore, the paper emphasizes the importance of managing emotions in public services. Finally, it also considers how the quality assessment of public services should take into account implications regarding value to society. The outcome is a holistic model for assessing the quality of public services.
\end{abstract}

Keywords Public services · Service quality · Satisfaction. Dissatisfaction · Emotions

\section{Introduction}

In most western economies, the public sector has control over a significant share of economic resources. Modern public organizations have been in the centre of the political and academic debate, aiming at finding suitable new management alternatives (cf. Osborne and Gaebler 1992; Pollitt 1993, 1995; Moe 1994). More specifically, modern societies demand more efficiency and effectiveness from public agencies, with a clear respect for the rights of citizens, especially when it comes to

\author{
C. Carvalho \\ University Portucalense, Rua Dr. António Bernardino de Almeida, 541-619, 4200-072 Porto, Portugal \\ e-mail: claudiap@uportu.pt \\ C. Brito ( $\because$ ) \\ Faculty of Economics, University of Porto, Rua Roberto Frias, 4200-464 Porto, Portugal \\ e-mail: cbrito@fep.up.pt \\ J. S. Cabral \\ Faculty of Engineering, University of Porto, Rua Roberto Frias, 4200-465 Porto, Portugal \\ e-mail: jacabral@fe.up.pt
}


equity and management of conflicting interests (cf. Frederickson 1994; Moe 1994; Schachter 1995; Mintzberg 1996; Denhardt and Denhardt 2000; Fountain 2001). The first two challenges are clearly aligned with the principles of New Public Management (NPM). Although some differences can be found from country to country, Pollitt (1995) points out eight essential elements of NPM: cost cutting, disaggregating traditional bureaucratic organizations into separate agencies, decentralization of management authority within each public agency, separating the functions of public service provision from purchasing, introducing market and quasi market-type mechanisms, requiring staff to work to performance targets, indicators and output objectives, establishing greater flexibility in public employment and, finally, increasing emphasis on service quality and customer responsiveness. In short, NPM aims at meeting the needs of the citizen rather than the bureaucracy.

Detractors of the most liberal public management trends have raised new concerns, namely those related to ethics (cf. Goodsell 1993; Cohn 1997; Johnston and Callender 1997; Dixon et al. 1998; Köning 1999; Pollitt and Bouckaert 2000; Haque 2001), giving priority to other topics, such as citizenship, trust, transparency and democratic dialogue (Frederickson 1994; Moe 1994; Schachter 1995; Mintzberg 1996; Denhardt and Denhardt 2000; Fountain 2001; Bovaird and Loffler 2002). Although there is some heterogeneity among reforms throughout the industrialized world (cf. Hesse and Benz 1990; Wright 1994; Benz 1995; Hood 1996; Peters 1996), research is clearly dominated by the concerns and issues that come from English-speaking countries: decentralization, focus on performance and quality, priority to the citizen, delivery and responsiveness improvement, stronger accountability, deregulation and privatization.

In this context, it became urgent to rethink the delivery of public services in order to increase their quality (Roy and Seguin 2000; Ling 2002), thereby satisfying the public's needs and, as far as possible, trying to please people and companies, favouring good governance and national economic competitiveness. In practice, several measures have been implemented in order to put into practice a new philosophy of public management based on the principles of New Public Management. More specifically, modern states have assumed significant responsibilities, in which more and more actors take part-private and semi-private entities-resulting in a growing fragmentation of a huge public sector which, generally speaking, does not correspond to the user's perspective. However, it is understood that citizens have a clear preference for resolving their official obligations having the least contact with the Administration as possible (cf. Hagen and Kubicek 2000; Keast and Brown 2002; Ling 2002; Moran 2005). In this context, coordination between public organizations became a central issue (cf. Hagen and Kubicek 2000; Bovaird 2001; Pollitt 2003), and there has been a trend toward concentration of public services on the basis of one-stop shopping, made possible by the significant advances in information and communications technology (Toonen and Raadschelders 1997).

As a result, it has become necessary to evaluate the impact of these modern alternatives, which is not a simple mission (Entwistle and Martin 2005). The practical impact of coordination, in its various dimensions, has to be assessed with citizens (cf. Wirtz and Tomlin 2000; Vigoda-Gadot 2000; Osborne and Gaebler 1992), civil servants (cf. Schneider and Bowen 1985) and other stakeholders- 
politicians, consultants, managers, professionals (Pollitt 2003)-because there may be conflicting interests that must be taken into consideration (cf. Freeman and Reed 1983; Freeman 1984).

Furthermore, there are also a number of relevant conceptual and methodological considerations. Firstly, as we are dealing with services, public service quality can be considered from the services marketing perspective. In fact, it was in the 80s that service quality became a central topic of research (cf. Parasuraman et al. 1985), namely because of growing competition among organizations in an increasingly competitive world. On the other hand, although the importance of quality management in the public arena is widely recognized (cf. Pollitt and Bouckaert 2000; Doherty and Horne 2002; Talbot et al. 2005), there is a debate on the meaning of public service quality (cf. Mintzberg 1986; Walsh 1991; Swiss 1992; Radin and Coffee 1993; Hazlett and Hill 2000). In fact, the concept and measurement of service quality have been among the most controversial issues in the services marketing debate (Brady and Cronin 2001). Assessing the quality of services is much more complex than when we are dealing with products, because services are "deeds, acts or performances" (Berry 1980), and have specific characteristics-intangibility, inseparability between production and consumption, perishability and heterogeneity (cf. Berkowitz et al. 1986)—which make them unique (cf. Grönroos 1990; Kotler and Andreasen 1995).

In the literature there has been strong debate about the transfer of quality concepts from the private to the public sector. While those who advocate Total Quality Management argue that large private companies and public organizations tend to face the same bureaucratic issues, the more critical views contend that they operate under very distinct frameworks (cf. Halachmi 1995). In fact, as in most western economies the dichotomy between those two sectors tends to fade with a growing cooperation between public, private and volunteer sectors, the use of those concepts and guidelines has not been a simple issue (Swiss 1992). In practice, most of the models for quality assessment are not suited to public services, especially if they do not operate under market conditions. Public agencies that are strongly oriented by political objectives experience great difficulty in thinking and acting in a TQM perspective (Loffler 2001).

Nevertheless, although the adoption of models and instruments designed for private initiative is not free from criticism or caution (cf. Swiss 1992; Rago 1994; Halachmi 1995), others claim that as the frontiers between the two sectors are fading, it is feasible to use those constructs in public service research (Cohen and Eimicke 1994; Rago 1994; Gaster 1995). Additionally, although it is believed that quality is what we can measure and control, unfortunately not every service quality item can be measured. There are many subjective aspects that are difficult, or even impossible, to measure within a quantitative framework-for instance, a smile, a courtesy, a word of support or a kindness. So, only a multidimensional construct, measured with both quantitative and qualitative indicators, can capture their global effects.

In this context, this paper has a twofold objective. Firstly, to contribute to an understanding of satisfaction and dissatisfaction with public services. Secondly, to present a model that aims at evaluating the quality of the public service, considering three main components: the interaction process involved in the public service, the 
citizen's perceptions of quality, and the value created for society. The paper is divided into five sections. After this introduction, the paper reviews the literature on the main elements of public service quality in Section 2. Then we address the research questions and suggest a conceptual framework for analysing quality of public services. Section 4 elaborates on the methodological approach that can be adopted in this sort of investigation. Finally, conclusions are drawn in Section 5.

\section{Literature review}

\subsection{Interaction in public services}

In this research, public services are viewed as a pseudo-relationship-i.e., a "repeated contact between a customer and a provider-organization" (Gutek 2000, p. 372). A pseudo-relationship means that the customer identifies the service but not a particular person as its supplier, not anticipating any future interaction with a particular provider but, instead, with the organization. Therefore, in the marketing literature the term "pseudo-relationship" does not have any pejorative meaning, and is merely descriptive.

A pseudo-relationship can be seen as a series of episodes-encounters/moments of truth-or as successive individual interactions between the customer and the supplier of the service. Each episode can be defined as an interaction event that has a clear beginning and an end. According to Gutek (2000), these successive contacts involve different service employees, and it is assumed that each one is functionally equivalent to the others. Thus, although most of the models and instruments of quality are essentially static, it is important to look at this type of relationship as being a dynamic process. Traditionally, only the quality of a specific episode was considered, and the fact that the customer perception about service quality evolves as he/she continues to use the service was not taken into account. But services are processes, customers' perceptions evolve, and so the approach must be dynamic. The implications of this perspective are enormous, because an unsatisfactory episode may not put an end to the relationship if previous episodes have been satisfactory. Therefore, satisfaction and dissatisfaction of the customer/user of public services must be analyzed as cumulative variables.

In this work, contact with a public service is viewed as an experience, which can vary between a mere series of episodes-encounters/moments of truth-and, at the other extreme, a relationship. In fact, the aim is not to evolve from the former to the latter, because the citizen may not really be looking for a true relationship with the service he/she is using. Instead, the focus has to be on increasing his/her degree of satisfaction with the experience. Furthermore, public services also involve true internal relationships, between the public agency and its own civil servants. We may then consider that the public service results from the relationship between three parts: the citizen, the public agency and society (including here all other stakeholders).

Consequently, it is absolutely essential to clarify who the users of public services are-citizens, customers, beneficiaries or others? Some authors contend that the adoption of a private-sector-style customer focus is inappropriate in the public 
sector, arguing that it devalues citizenship. Alford (2002) presents a very interesting typology based on the idea that most interactions between the public sector and the client differ from the private sector transaction. As he points out, "citizenry constitutes an authoritative judgement that legitimizes the values realized or delivered by government organizations. However, it is very different from the customer function in a number of important respects" (op. cit., p. 339). Citizenship confers rights and responsibilities on every citizen. For the author, in the public sector, both the citizenry and the clients consume value produced by government, but each receives a different type of value. "The citizenry receives public value, whereas clients receive private value" (Alford 2002, p. 339). Citizen relates to the public services collectively, whereas those who have a more direct interaction are more like customers - the paying customer (when buying a subway ticket), the beneficiary (who receives the service or benefit without paying directly in return) or the obligatee (who receives the service against his/her will, such as a prisoner, for example). But in every transaction with public service organisations, each member of the public is simultaneously a citizen and a customer (fitting at least into one of the three roles). In this paper, we use the term citizen in order to avoid excessive terminology.

\subsection{Service quality}

There are two main paradigms in research into service quality: the expectationdisconfirmation paradigm and the performance paradigm. For the former, perceived service quality results from the comparison between performance and expectations (Oliver 1980). Although it is agreed that there are multiple quality dimensions, there is no consensus as to their number and nature: two (cf. Grönroos 1982; Lethinen and Lethinen 1982; Mels et al. 1997), three (Rust and Oliver 1994), five (Parasuraman et al. 1988) and ten (Parasuraman et al. 1985, in the original version of SERVQUAL). On the other hand, the performance paradigm argues that expectations are irrelevant and only performance should be considered.

These two perspectives gave rise to two alternative frameworks: SERVQUAL (Parasuraman et al. 1985; Zeithaml et al. 1988) and SERVPERF (Cronin and Taylor 1992). Even though they are widely used in quality assessment of services, some authors claim that they are not generic and, consequently, a number of adaptations should be made for each specific context (cf. Carman 1990; Finn and Lamb 1991; Dabholkar et al. 2000; Zhao et al. 2002). There are other developments in the literature, such as modified versions of SERVQUAL and the importanceperformance paradigm proposed by Martilla and James (1977). In our view, it is possible to adapt the frameworks designed for private services to assess public service quality. Thus, our model considers both citizens' expectations and perceptions.

Although it is consensual that customer satisfaction is essential for organization success (cf. Vavra 1997; Dabholkar et al. 2000; Keiningham et al. 2003; Fornell et al. 2006; Stradling et al. 2007), there is no agreement on the relation between quality and satisfaction. Luo and Homburg (2007) present a clear and complete systematization of customer satisfaction outcomes and the respective academic articles. Similarly, there is no universal definition of satisfaction (cf. Yi 1990; 
Peterson and Wilson 1992). Indeed, for some authors satisfaction is an evaluation process (cf. Hunt 1977; Oliver 1980; Fornell 1992), but for others it is the answer to that evaluation process (cf. Howard and Sheth 1969; Oliver 1980, 1997; Westbrook and Reilly 1983; Tse and Wilton 1988). It can also be viewed as a cognitive answer (cf. Howard and Sheth 1969; Tse and Wilton 1988; Bolton and Drew 1991) or an effective response (Westbrook and Reilly 1983; Cadotte et al. 1987). Besides, some authors argue that satisfaction precedes quality (Parasuraman et al. 1988; Bitner 1990; Bolton and Drew 1991), while others support the opposite (Oliver 1993; Parasuraman et al. 1994; Cronin and Taylor 1994; Liljander and Strandvik 1995; Fornell et al. 1996; Grönroos 2000; Brady et al. 2002).

Most expectations and satisfaction research focused on services from the private sector and the relation between the disconfirmation of expectations and satisfaction with public services is still barely explored (Roch and Poister 2006), although there has been some research in this area, concluding that disconfirmation is positively related to satisfaction with public services (cf. Beck et al. 1990; DeHoog et al. 1990; Van Ryzin 2004). However, it is not possible to generalize, and more investigation needs to be done. The next section elaborates on these issues with a particular emphasis on the concepts of satisfaction and dissatisfaction.

\subsection{Satisfaction versus dissatisfaction}

There is still no consensus on the relation between satisfaction and dissatisfaction. Although some literature has stressed the importance of satisfaction maximisation and dissatisfaction minimization, this approach has been neglected in most empirical work on services (Dawes and Rowley 1999; Liljander 1999). Service quality literature looks to identify the dimensions or attributes that generate positive evaluations of quality by customers. In effect, there is a preference here for understanding and defining positive concepts such as quality and satisfaction, instead of the negative ones that result in dissatisfaction.

However, satisfaction and dissatisfaction with services cannot be considered opposites (Bleuel 1990; Johnston 1995), because controlling dissatisfaction may not necessarily lead to satisfaction. As Findlay (1967) explains, the aversion system has greater influence on behaviour than the pleasure system, as dissatisfaction is stronger and more lasting than satisfaction. In fact, it seems there is not a univocal correspondence between these two concepts. Some empirical works conclude that the elements of satisfaction are not the same as those of dissatisfaction and, subsequently, one is not the mere opposite of the other.

Similarly, researchers from other fields of knowledge have also pointed out the importance of dissatisfaction analysis, without considering it merely the opposite of satisfaction. This is the case of Scitovsky (1976) in neurophysiology and Herzberg (1968) in psychology (stressing the difference between motivational and hygiene factors). Kano and his colleagues (1984) also addressed this perspective in their quality investigation distinguishing between the basic needs (in this case, customers become dissatisfied when performance is low, but satisfaction does not rise above neutral with high performance), the one-dimensional needs (when satisfaction is a linear function of performance) and the attractive or excitement needs (when satisfaction increases super-linearly with performance, but will not decrease below 
neutral if there is a decrease in performance-usually unexpected features, that fulfil latent or unknown needs).

In fact, when we consider the concerns of customers with information accuracy, waiting time, attendance duration, bad attendance, and so forth (negative incidents) satisfaction becomes to some extent a secondary concern (Johnston 1995; Dawes and Rowley 1999). But as long as minimum quality criteria are respected dissatisfaction tends to decrease. In short, without a strategy that includes both dissatisfaction removal and increase of satisfaction, employees and customers might become sceptical about the attempts to improve service quality in the organization. Therefore it is important to identify the authentic sources of dissatisfaction. These results can be used to establish a priority for corrective measures, namely in terms of back-office rearrangements.

Accordingly, satisfaction and dissatisfaction are core aspects of our model. They are not considered to be opposites. The basic idea is to understand how public services may progress from the stage of mere appeasement to user satisfaction, aiming to delight the citizen. In practice, the information gathered can be used to establish priorities for the corrective measures, as a means of increasing loyalty towards public services, which is especially important for some areas facing competition. In fact, when we are dealing with monopolized services, if the source of the monopoly disappears as a result of deregulation, for instance, dissatisfied customers will most certainly defect. "Even in markets with relatively little competition, providing customers with outstanding value may be the only reliable way to achieve sustained customer satisfaction and loyalty" (Jones and Sasser 1995, p. 89). Merely satisfying customers will not keep them loyal. Furthermore, now citizens expect more accountability from governments, as Milakovich (2003, p. 75) makes clear: “...they want accountable, efficient, fair and effective value for their scarce resources". To sum up, it is crucial to identify the causes. Therefore, our model considers both the determinants that tend to be sources of satisfaction and those which cause dissatisfaction. Nonetheless, besides this issue, other factors tend to affect the perceptions of citizens regarding the public service. These include the zone of tolerance and the emotions that will be addressed in the next section.

\subsection{Zone of tolerance and emotions}

The concept of "zone of tolerance"-accepted service performance level somewhere between the adequate and desired level of expectations-was introduced by Berry and Parasuraman (1991) but barely applied to public service quality research. In fact, customers usually recognize that it is not always possible to attain their expectations, and accept an inferior service level without feeling dissatisfied. Indeed, satisfied customers can have a series of negative experiences that reduce their level of satisfaction but that do not make them unsatisfied. Situational factors, previous experiences and word-of-mouth may help to redefine their expectations. Similarly, the Liljander and Strandvik model (1995) recognizes the importance of the zones of tolerance-admitted variations of the levels of performance of service inside certain limits, where any increase of performance in this area will have only small effects on the perceptions. It is still thought that the zone of tolerance can be extended to the level of relationship, capturing the accumulated variance of performance. 
The existence of a zone of tolerance is inherent to the condition of "service"customers tend to accept its heterogeneity that leads to variation in performance (Zeithaml et al. 1996). Above this level they feel delighted and below they feel dissatisfied. In this sense, our model considers that citizens may admit that their expectations may not always be met, and therefore accept a service performance level somewhere between the adequate and desired level of expectations and still not feel dissatisfied.

Emotions exert a great influence on tolerance and, consequently, on satisfaction, because individuals may already have a predisposition to see incidents as positive or negative. Thus, Johnston (1995) contends that the evaluation of a particular episode may not result from incidents, since satisfaction can be essentially related to the customer's mood when he or she receives the service. So, the role of emotions should be carefully analyzed. In fact, the positive and negative emotions that customers associate with the service have growing importance in literature in the creation of satisfaction. Customers experience positive and negative emotions related to the service and these emotions influence their degree of satisfaction. However, there is still a lack of research on the linkage between emotions and postconsumption variables, such as satisfaction (Liljander and Bergenwall 1999), and on the role of service recovery, which may change negative emotions into positive ones, in customer emotions management. In fact, with few exceptions (cf. Bitner 1992; Tsiros and Mittal 2000; Bonifield and Cole 2007) most service models have not considered emotions.

Several definitions of emotions have appeared in the psychology literature but there is no consensus and it may be harmful to use too narrow a notion. Oliver (1997, p. 294) considers that "emotion includes arousal, various forms of affect, and cognitive interpretations of affect that may be given a single description". Therefore, in distinct segments, customers may react with different emotions to the same service. This means that, due to the variability of services, the same customer may have different levels of perceived quality of the service or distinct emotions from one episode to another. For the manager it is a challenge to understand these emotions, as well as to analyze their intensity and frequency (Friman et al. 2001) and manage them to promote positive emotions and reduce the negative ones.

In fact, it has been shown that customers experience both positive and negative emotions related to the service and that these emotions influence their satisfaction. The negative emotions have the biggest impact on the customer's reaction and the positive emotions have been associated with satisfaction increase. On the other hand, satisfaction is also seen as having an affective dimension, without which the customers' behaviour cannot be fully explained. It is thought that the affective processes are partially out of the conscious control of customers.

Besides, the type and force of emotions that result from one or more negative incidents in a relationship can better explain the termination than the source of the incident itself, even in cases where service quality is low. This has not been fully studied, and neither has the role of service recovery in customer emotions management. These considerations also find echo in the context of public services. Vigoda-Gadot (2000) recognizes the lack of research in this field, but explains that it is extremely important to understand citizens' feelings and reactions when they contact public services. Accordingly, the model proposed in this paper considers the influence of emotions on the quality of the service provided by public agencies. 


\subsection{Value for society}

Besides the relationship between the citizen and the public agency, public services also involve society in general. In fact, modern management perspec- tives have changed focus from the shareholders to a broader viewoint that includes an increasing set of stakeholders that in some way relate to the organization. In the literature, the relevance of these stakeholders has been stressed by academics (cf. Freeman 1984; Evan and Freeman 1988; Preston and Sapienza 1990; Hoyle 1994; Foley and Barton 1997; Foster and Jonker 2003). In this sense, quality management should not only focus on internal operations, but should also consider all those groups that in some way relate to the organization. Thus, business quality is seen as the capability of serving society as a whole (Hoyle 1994).

In this context, the stakeholders' theory has been developed, based on the idea that the objectives of any organization should take into consideration the stakes of the various groups that in some way relate to that organization, namely managers, employees, shareholders and suppliers (Freeman and Reed 1983). Furthermore, it argues that its success depends on the relationships between the organization and those stakeholders. In the same way, social responsibility has also been receiving growing attention (Foley 1999; Foster and Jonker 2003).

This perspective has some similarities with Taguchi's concept of quality: quality is viewed as the loss that a product causes to society "after being shipped, other than any losses caused by its intrinsic functions" (Stocker 1990, p. 35). This means that all the product characteristics that deviate from the intended value cause losses to society. Thus, it is a different approach to the traditional one, according to which the final objective is the maximization of individual profit. Taguchi's perspective aims at the minimization of the loss to society. For Ribière et al. (1999, p. 2) this perspective "though initially used in manufacturing can easily be applied to the service industry". For some services, such as health services, the monetary loss is not the most important thing, and it is therefore essential to capture and to analyze the causes of customers' dissatisfaction.

In particular, public agencies also relate to a wide set of social groups that sometimes have conflicting interests: citizens, clients, beneficiaries, central and local government, associations, private companies, among others. For this reason, a lot of research on public service quality takes these stakes into consideration (cf. Doyle 1994; Atkinson et al. 1997; Provan and Milward 2001; Neely et al. 2002; Bourne et al. 2003; Ferlie et al. 2004) and understands the impact of public service delivery in terms of losses to society, considered here as all other stakeholders besides the public agency itself.

\section{A conceptual model for the evaluation of public service quality}

The aim of this conceptual research is to contribute to a better understanding of public service quality. In this sense, the central problem of the investigation is:

\& What are the determinants of public service quality? 
Given this central problem, the study focuses on three key research questions:

1. How is the interaction process developed in the public service encounter?

2. How are citizens'/user's perceptions of public service quality formed?

3. What is the impact of public service quality on the value to society?

It is important to clarify these research questions because they are on the basis of our conceptual model. This is divided into three main parts, which allows a clear association between each of the three research questions and the levels of analysis (Fig. 1).

In the first part, the relationships that are developed during the public service encounter between the citizen, the public agency and society (all stakeholders involved), are explored, considering the public service encounter as a succession of episodes-a pseudo-relationship-involving all those stakeholders. In fact, in most cases public services involve repeated contact and the citizen does not anticipate any future interaction with a particular person, but instead with the organization in general. In the second part of the model, citizens' perceived quality is determined by comparing perceptions and expectations, which can result from previous experiences, word-of-mouth, suggested positioning and personal needs. Additionally, customers' and employees' emotions are considered to exert a significant influence on citizens' perceptions, because this encounter seems to be strongly relational and emotions are considered to have an important influence on the evaluation of each episode. In this context, the model admits certain variations in the level of performance, influenced by emotions and other factors external to the organization. A segmented analysis of customers/users is proposed, given the importance of the diversity of their characteristics in the evaluation of the service quality.

Moreover, the model considers a zone of tolerance, in the sense that citizens may admit that their expectations may not always be met, and therefore accept a service performance level somewhere between the adequate and desired level of expectations and still not feel dissatisfied. In the third part, the model considers that public

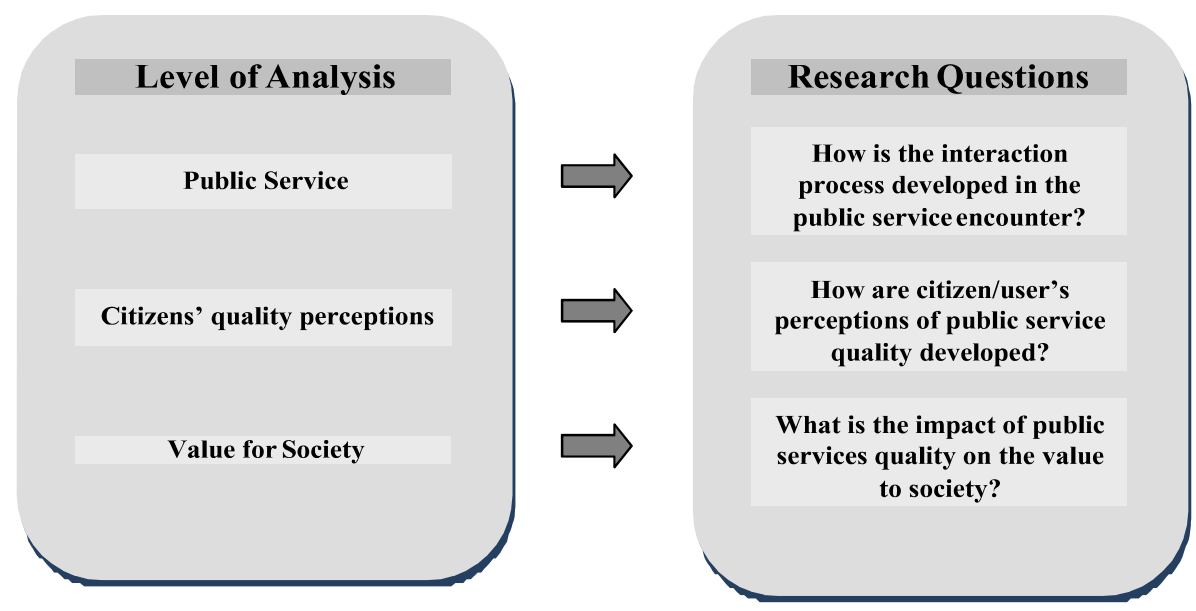

Fig. 1 Levels of analysis and research questions 
service quality results from both citizens' assessments and value to society, viewed as the relation between benefits and losses to all other stakeholders. Finally, the model considers that the quality of public services results from both citizens' assessments and value to society. In fact, if on the one hand the conception and delivery of public services aims to serve the citizens, making assessment of their perceptions crucial, Public Administrations involve a broad set of agents, and therefore it is also important to understand the impact on society in general. Figure 2 presents the model making clear the integration of the three research questions with each part of the framework.

\section{Methodological approach suggested}

This section aims to suggest a methodological approach to implement our conceptual and holistic model. From the literature of services marketing there are basically two ways of evaluating the quality of a given service (Schröder et al. 2000): attribute and incident based measurements. The first provides a general evaluation of the service quality-the customers evaluate more than only the result of the service, they also

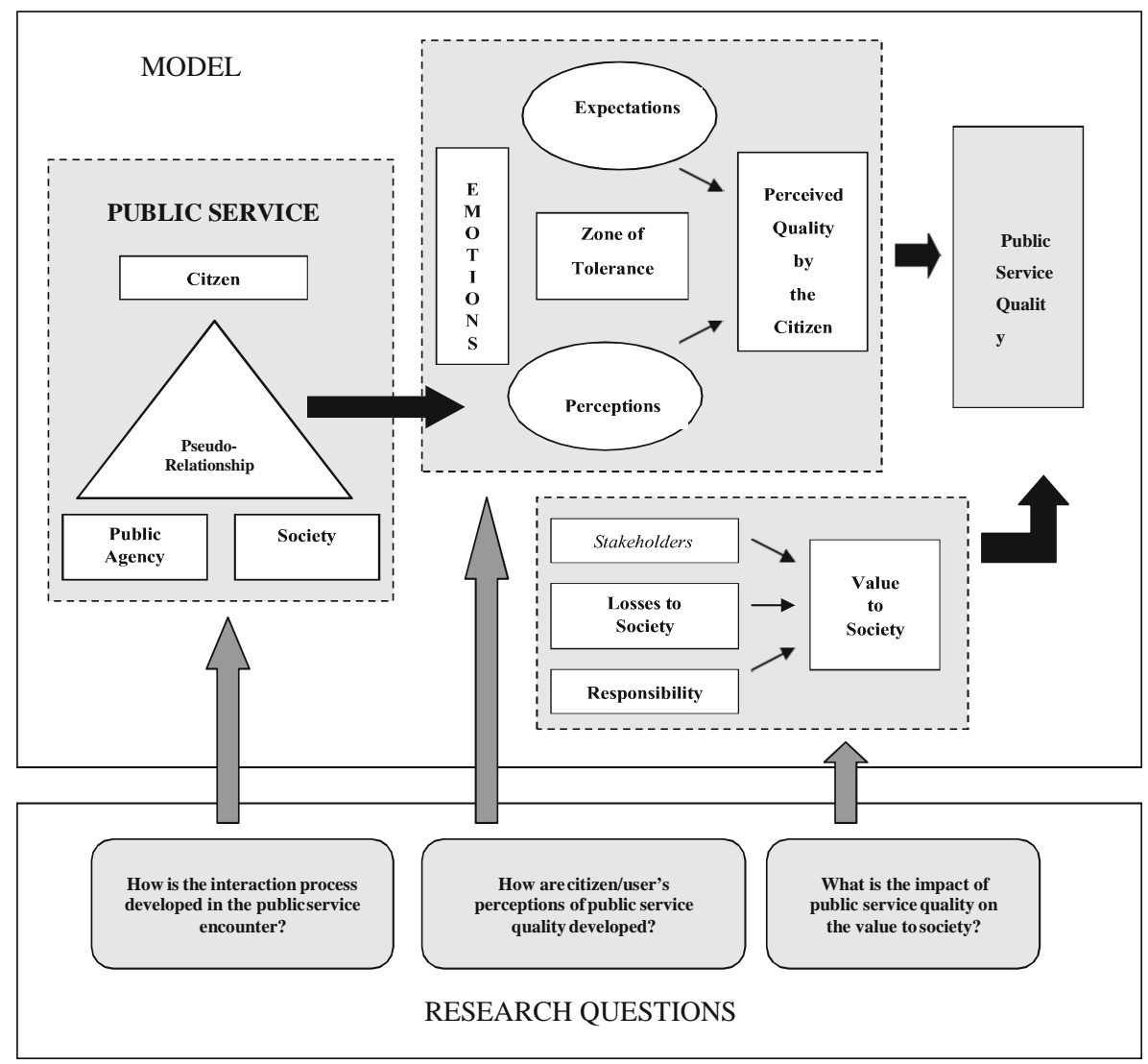

Fig. 2 Conceptual framework 
evaluate the process of service delivery and its dimensions/attributes. The incident based measurements emphasise the analysis of critical incident, defined as "specific interactions between customers and service firm employees that are especially satisfying or especially dissatisfying" (Bitner et al. 1990, p. 73)-for the definition of the determinants of satisfaction/dissatisfaction. In the academic field, researchers have presented some valuable investigation on the effects of these advances on the level of citizens' satisfaction, based mainly on the attribute-based models used for assessing service quality in the private arena. Nevertheless, public services have specific features that justify a specially designed framework for their evaluation.

Since citizens' perceptions of public services are still scarcely known, qualitative studies would seem to make a valuable contribution. Indeed, according to Yin (1994), exploratory research is the most suitable when the research questions are of the type "how?" and when the main purpose is to understand a subject that is still almost unknown. Therefore, a predominantly explanatory qualitative methodology can be adopted following a case-study approach, and using multiple sources of empirical evidence. Indeed, case-studies are considered a suitable methodology for exploratory and explanatory research (Yin 1994).

Moreover, we also suggest an adaptation of the Critical Incident Technique-CIT (Flanagan 1954). This technique was introduced into the marketing literature by Swan and Rao (1975) and in the services marketing arena by Bitner et al. (1990). Since then, many studies have been based on CIT adaptations (cf. Edvardsson 1988, 1992; Bitner 1990; Stauss and Hentschel 1992; Stauss 1993; Strandvik and Liljander 1994; Keaveney 1995; Stauss and Weinlich 1997; Bostschen et al. 1996; Olsen 1996; Roos and Strandvik 1996; Roos 1996, 1999; Decker and Meissner 1997). The incidents can be collected with the citizens using a questionnaire and categorized according to the five dimensions proposed in SERVQUAL (Zeithaml et al. 1988). Besides this, all other qualitative data can be obtained by means of personal semistructured interviews (for instance, with managers and front and back-office public servants) and focus groups (for instance, with citizens and public servants). In fact, focus groups have been extensively used in services marketing research, and more recently their use has been explored in public service analysis (Krueger 1994).

Together with the main methodological option, an importance/performance analysis can also be undertaken based on data obtained with the questionnaire (Martilla and James 1977). This procedure does not conflict with the case-study methodology, which allows the use of qualitative and quantitative methods (Amaratunga and Baldry 2001; Jensen and Rodgers 2001). Data diversity may be considered one of the main contributions of this research, since triangulation strengthens constructs and hypotheses (Eisenhardt 1989). The analysis follows the principles of the grounded-theory approach aiming at the emergence of new theoretical constructs on the basis of the data analyzed (Strauss and Corbin 1990).

\section{Conclusion}

In a time of increasing budgetary constraints and demands from society-citizens and organizations - in relation to Public Administration, one of its major challenges is the creation of more value for both citizens and society in general. This implies 
satisfying citizens' needs with greater effectiveness, minimizing costs on the basis of an increased efficiency, and creating more value to society.

The paper has three main contributions: theoretical, methodological and managerial. Firstly, conceptual investigation suggests that public services involve a peculiar type of relationship. They present characteristics of pseudo-relationships involving three agents: the citizen, the public agency and society itself. Moreover, public service quality must be considered from the citizen viewpoint, regarding their expectations and perceptions. Additionally, the attributes can be classified as a source of satisfaction or dissatisfaction, or even neutral. The investigation addressed the existence of a certain degree of tolerance in citizens' public services assessments. Another contribution came from the importance given to emotions during the interaction process. Lastly, considering the special features of public services, our holistic conceptual model complements citizen quality assessment with evaluation from society. This addresses the benefits and losses to society, as well as opportunities for improvement.

Secondly, the combination of attribute based measures and incident analysis is the most significant methodological contribution, and is likely to be very useful to understand how citizens' perceptions are created. Besides, a dyadic approach can be used, considering both users' and civil servants' viewpoints. A great variety of data can be collected to be used in multiple ways, qualitatively and quantitatively, in order to get as much information as possible.

Lastly, from a managerial point of view, it is crucial to understand the determinants of public service quality. More specifically, this involves an understanding of the service encounter, citizens' perceptions and the impacts on society. This analysis may help managers to prevent the occurrence of negative incidents and develop abilities to deal with them in a professional way, even with those that, despite every effort, always happen. On the other hand, positive incidents must be regarded as learning experiences for the public agency. Constructs and frameworks designed to assess the quality of private services seem to be useful to the public context, but they need to be adapted to the specificities of the public service arena. That is why the central purpose of this research is to understand the determinants of public service quality. The focus on citizens' perspective within a highly relational framework, complemented by the analysis of the value to society, is likely to give new insights into public service assessment.

To sum up, we believe that our model represents a holistic approach for the study of the determinants of public service quality. The next step is its application to empirical contexts in order to evaluate its effectiveness in understanding such phenomena.

\section{References}

Alford J (2002) Defining the client in the public sector: a social-exchange perspective. Publ Admin Rev 62 (3):337-346

Amaratunga D, Baldry D (2001) Case study methodology as a means of theory building: performance measurement in facilities management organizations. Work Study 5(3):95-101

Atkinson AA, Waterhouse JH, Wells RB (1997) A stakeholder approach to strategic performance measurement. Sloan Manage Rev 38:25-37 
Beck PA, Raney HG, Traut C (1990) Disadvantage, disaffection and race as divergent bases for citizen fiscal policy preferences. J Polit 52(1):1-93

Benz A (1995) Institutional change in intergovernmental relations: the dynamics of multi-level structures. In: Hesse JJ, Toonen TAJ (eds) European yearbook of comparative government and public administration. Nomos Verlagsgesellschaft, Baden-Baden, pp 551-576

Berkowitz EN, Kerin RA, Rodelius W (1986) Marketing. Times Mirror, Mosby College Publishing, St. Louis

Berry LL (1980) Services marketing is different. Business 30:24-29

Berry LL, Parasuraman A (1991) Marketing services: competing through quality. The Free Press, Macmillan

Bitner M (1990) Evaluating service encounters: the effects of physical surroundings and employee responses. J Mark 54:69-82

Bitner M (1992) Servicescapes: the impact of physical surroundings on customer and employees. J Mark 56(2):69-82

Bitner M, Booms B, Tetreault M (1990) The service encounter: diagnosing favorable and unfavorable incidents. J Mark 54:71-84

Bleuel B (1990) Commentary: customer dissatisfaction and the zone of uncertainty. J Serv Mark 4-1:4952

Bolton RN, Drew JH (1991) A multistage model of customers' assessment of service quality and value. J Consum Res 17:375-384

Bonifield C, Cole C (2007) Affective responses to service failure: anger, regret, and retaliatory versus conciliatory responses. Market Lett 18(1/2):85-99

Bostschen G, Bstieler L, Woodside A (1996) Sequence-oriented problem identification within service encounters. J Euro-Mark 5(2):19-52

Bourne M, Neely A, Mills J, Platts K (2003) Implementing performance measurement systems: a literature review. International Journal of Business Performance Management 5(1):1-24

Bovaird T (2001) Excellent organisations, effective service systems and successful communities: towards the evaluation of governance mechanisms. BBS Teaching and Research Review, issue 5, Winter, 1-10

Bovaird T, Loffler E (2002) Emerging trends in public management and governance. BBS Teaching and Research Review, issue 5, Winter

Brady M, Cronin J (2001) Some new thoughts on conceptualizing perceived service quality: a hierarchical approach. J Mark 65:34-49

Brady MK, Cronin JJ, Brand RR (2002) Performance-only measurement of service quality: a replication and extension. J Bus Res 55(1):17-31

Cadotte ER, Woodruff RB, Jenkins RL (1987) Expectations and norms in models of consumer satisfaction. J Mark Res 24:305-314

Carman JM (1990) Consumer perceptions of service quality: an assessment of the servqual dimensions. J Retail 66(1):33-55

Cohen S, Eimicke W (1994) Project-focused total quality management in new york city department of parks and recreation. Publ Admin Rev 54(5):450-456

Cohn D (1997) Creating crises and avoiding blame: the politics of public service reform and the new public management in Great Britain and the United States. Adm Soc 29(5):584-616

Cronin J, Taylor S (1992) Measuring service quality: a reexamination and extension. J Mark 56(3):55-68

Cronin J, Taylor S (1994) SERVPERF versus SERVQUAL: reconciling performance-based and perceptions-minus-expectations measurement of service quality. J Mark 58:125-131

Dabholkar PA, Shepherd CD, Thorpe DI (2000) A comprehensive framework for service quality: an investigation of critical conceptual and measurement issues. J Retail 76(2):139-173

Dawes J, Rowley J (1999) Negative evaluations of service quality—a framework for identification and response. J Mark Pract Appl Mark Sci 5(2):46-55

Decker A, Meissner H (1997) The Sequential Incident Technique for Innovations (SITI)—an instrument for generating improvements and ideas in services processes, Diskussionsbeiträge der Wirtschaftswissenschaftlichen Fakultät Ingolstadt, $n^{\circ}$ 87, Catholic University of Eichstaett

DeHoog R, Lowery D, Lions WE (1990) Citizen satisfaction with local governance: a test of individual, jurisdictional and city-specific explanations. J Polit 52(3):807-837

Denhardt RB, Denhardt JV (2000) The new public service: serving rather than steering. Publ Admin Rev 60(6):549-559

Dixon J, Kouzmin A, Korac-Kakabadse N (1998) Managerialism-something old, something borrowed, little new, economic prescription versus effective organizational change in public agencies. Int $\mathbf{J}$ Public Sect Manag 11(2/3):164-187 
Doherty TL, Horne T (2002) Managing public services-implementing changes: a thoughtful approach. Routledge, London

Doyle P (1994) Setting business objectives and measuring performance. Journal of General Measurement 20(2):1-19

Edvardsson B (1988) Service quality in customer relationships: a study of critical incidents in mechanical engineering companies. Serv Ind J 8:427-445

Edvardsson B (1992) Service breakdowns - a study of critical incidents in an airline. Int J Serv Ind Manag 3(4):17-29

Eisenhardt KM (1989) Building theories from case-study research. Acad Manag Rev 14(5):532-550

Entwistle T, Martin S (2005) From competition to collaboration in public service delivery: a new agenda for research. Public Adm 83(1):233-242

Evan WM, Freeman RE (1988) A stakeholder theory of he modern corporation: Kantian Capitalism. In: Beauchamp T, Bowie N (eds) Ethical theory and business. Prentice-Hall, Englewood Cliffs, pp 75-93

Ferlie E, Hartley J, Martin S (2004) Changing public service organizations: current perspectives and future prospects. Br J Manage 14(issue s1):1-14

Findlay JN (1967) Values and intentions: a study in value theory and philosophy. Humanities Press, New York

Finn DW, Lamb CW (1991) An evaluation of the servqual scale in a retailing setting. In: Holman R, Solomon MR (eds) Advances in consumer research, vol 18. Association for Consumer Research, Provo, pp 480-493

Flanagan J (1954) The critical incident technique. Psychol Bull 51(4):327-358

Foley K (1999) What is quality management? Centre for Quality Management Research, RMIT University, Melbourne

Foley K, Barton R (1997) Quality, productivity and competitiveness. Standards Australia, Strathfield

Fornell C (1992) A national customer satisfaction barometer: the Swedish experience. J Mark 56(1):6-21

Fornell C, Johnson MD, Anderson EW, Cha J, Bryant BE (1996) The American customer satisfaction index: nature, purpose and findings. J Mark 60(4):7-18

Fornell C, Mithas S, Morgeson F, Krishan M (2006) Customer satisfaction and stock prices: high returns, low risk. J Mark 70(issue 1):3-14

Foster D, Jonker J (2003) Third generation quality management - the role of stakeholders in integrating business into society. Manag Audit J 18(4):323-328

Fountain J (2001) Paradoxes of public sector customer service. Governance: An International Journal of Policy and Administration 14(1):55-73

Frederickson H (1994) The seven principles of total quality politics. Public Adm times 17(1):9

Freeman R (1984) Strategic management: a stakeholder approach. Pitman, Boston

Freeman R, Reed DL (1983) Stockholders and stakeholders: a new perspective on corporate governance. Calif Manage Rev 25(3):88-106

Friman M, Edvardsson B, Gärling T (2001) Frequency of negative critical incidents and satisfaction with public transport services. J Retail Consum Serv 8:95-104

Gaster L (1995) Quality in public services: managers' choices. Open University Press, Buckingam

Goodsell C (1993) Reinventing government or rediscover it? Publ Admin Rev 53(3):85-87

Grönroos C (1982) Strategic management and marketing in the service sector. Research Reports

Grönroos C (1990) Service marketing and management-managing the moments of truth in service competition. Lexington Books, Toronto

Grönroos C (2000) Service management and marketing-a customer relationship management approach, 2nd edn. Wiley, West Sussex

Gutek B (2000) Service relationships, pseudo-relationships, and encounters. In: Swartz T, Iacobucci D (eds) Handbook of services marketing \& management. Sage Publications, Thousand Oaks, pp 371-380

Hagen M, Kubicek H (2000) One-stop-government in Europe-results of 11 national surveys. University of Bremen, Bremen

Halachmi A (1995) Measure of excellence. In: Hill H, Klages H, Loffler E (eds) Quality, innovation and measurement in the public sector. Verlag, Frankfurt, pp 9-23

Haque SM (2001) The diminishing of publicness of public service under the current mode of governance. Publ Admin Rev 61(1):65-82

Hazlett SA, Hill F (2000) Policy and practice: an investigation of organizational change for service quality in public sector in Northern Ireland. Total Qual Manag 11(4-6):515-520

Herzberg F (1968) One more time: how do you motivate employees? Harvard Bus Rev 46(1):53-62

Hesse JJ, Benz A (1990) Die Modernisierung der Staatsorganisation. Institutionspolitik im Internationalen, Vergleich: USA. Nomos Verlagsgesellschaft, Baden-Baden 
Hood C (1996) Exploring variations in public management reforms of the 1980's. In: Bekke H, Perry J, Toonen $\mathrm{T}$ (eds) Civil service systems in comparative perspective. Indiana University Press, Bloomington

Howard JA, Sheth JN (1969) The theory of buyer behaviour. Wiley, New York

Hoyle D (1994) ISO 9000 quality systems handbook. Butford Technical Publishing, Bodenhamy

Hunt HK (1977) CS/D-overview and future research directions. In: Hunt HK (ed) Conceptualization and measurement of consumer satisfaction and dissatisfaction. Marketing Science Institute, Cambridge, pp $300-332$

Jensen J, Rodgers R (2001) Cumulating the intellectual gold of case-study research. Publ Admin Rev 61 (2):235-248

Johnston R (1995) The zone of tolerance: exploring the relationship between service transactions and satisfaction with the overall service. Int J Serv Ind Manag 6(2):46-61

Johnston J, Callender G (1997) Vulnerable governments: inadvertent de-skilling in the new global economic and managerialism paradigm? International Journal of Administrative Sciences 63:41-56

Jones TO, Sasser WE (1995) Why satisfied customers defect. Harvard Business Review, Nov.-Dec., 8899

Kano N, Seraku K, Takahashi F, Tsuji S (1984) Attractive quality and must-be quality. The Journal of the Japanese Society for Quality Control 14(2):39-48

Keast R, Brown K (2002) The government service delivery project-a case study of the push and pull central government coordination. Publ Manag Rev 4(4):439-459

Keaveney S (1995) Customer switching behaviour in service industries: an exploratory study. J Mark 59:71-82

Keiningham T, Perkins-Munn T, Evans H (2003) The impact of customer satisfaction on share-of-wallet in a business-to-business environment. J Serv Res 6(1):37-50

Köning K (1999) Good governance—as steering and value concept for the modern administrative state. In: Corkery J (ed) Gouvernance: concepts et applications. IISA, Bruxelles

Kotler P, Andreasen AR (1995) Strategic marketing for non-profit organizations. In: Baker MJ (ed) Companion encyclopedia of marketing. Routledge, New York, pp 930-950

Krueger RA (1994) Focus groups: a practical guide for applied research, 2nd edn. Sage Publications, Thousand Oaks

Lethinen U, Lethinen J (1982) Service quality-a study of quality dimensions. Research Report: Helsinki Management Institute

Liljander V (1999) Customer satisfaction with complaint handling following a dissatisfactory experience with car repair. European Advances in Consumer Research 4:270-275

Liljander V, Bergenwall M (1999) Consumption-based emotional responses related to satisfaction. Working Paper $\mathrm{n}^{\circ} 396$, Swedish School of Economics and Business Administration, Finland

Liljander V, Strandvik T (1995) The nature of customer relationships in services. In: Swartz T, Bowen D, Brown S (eds) Advances in services marketing and management, vol 4. JAI Press Inc, London

Ling T (2002) Delivering joined-up government in the UK: dimensions, issues and problems. Public Adm $80(4): 615-642$

Loffler E (2001) Defining and measuring quality in public administration. BBS Teaching and Research Review, issue 5, Winter

Luo X, Homburg C (2007) Neglected outcomes of customer satisfaction. J Mark 71:133-149

Martilla JA, James JC (1977) Importance-performance analysis. J Mark 41:77-79

Mels G, Boshoff C, Nel D (1997) The dimensions of service quality: the original European perspective revisited. The Services Industries Journal 17(1):173-189

Milakovich ME (2003) Balancing customer service, empowerment and performance with citizenship, responsiveness and political accountability. International Public Management Review 4(1):61-83

Mintzberg H (1986) Structures of organizations. Sage, New York

Mintzberg H (1996) Managing government, governing management. Harvard Bus Rev 74:75-83

Moe R (1994) The reinventing government exercise: misinterpreting the problem, misjudging the consequences. Publ Admin Rev 54:111-122

Moran T (2005) Regeneration-innovation and citizen-centred delivery. Aust J Public Adm 64(2):7-9

Neely A, Adams C, Kennerley K (2002) The performance prism. Financial Times, Prentice-Hall, London

Oliver RL (1980) A cognitive model of the antecedents and consequences of satisfaction decisions. J Consum Res 42:460-469

Oliver RL (1993) Cognitive, affective and attribute bases of the satisfaction response. J Consum Res 20:418-430

Oliver RL (1997) Satisfaction. A behavioral perspective on the consumer. McGraw-Hill, Inc, New York 
Olsen M (1996) The critical episode model as a tool for organizational learning in service organizations. In: Edvardsson B, Modell S (eds) Service management. Nerenius \& Santérus Förlag Ab, Stockholm

Osborne D, Gaebler T (1992) Reinventing government: how the entrepreneurial spirit is transforming the public sector from schoolhouse to statehouse, city hall to the Pentagon. Addison-Wesley, Reading

Parasuraman A, Zeithaml V, Berry LL (1988) SERVQUAL: a multiple-item scale for measuring consumer perceptions of service quality. J Retail 64(1):12-40

Parasuraman A, Zeithaml V, Berry LL (1985) A conceptual model of service quality and its implications for future research. J Mark 49:41-50

Parasuraman A, Zeithaml V, Berry L (1994) Reassessment of expectations as a comparison standard in measuring service quality: implications for future research. J Mark 58:111-124

Peters BG (1996) The future of governing: four emerging models. University Press of Kansas, Kansas

Peterson R, Wilson W (1992) Measuring customer satisfaction: fact and artifact. J Acad Mark Sci 20:61-71

Pollitt C (1993) Managerialism and the public service. Blackwell, Oxford

Pollitt C (1995) Justification by works or by faith?-Evaluating the new public management. Evaluation 1 (2):133-154

Pollitt C (2003) Joined-up government: a survey. Polit Stud Rev 1:34-49

Pollitt C, Bouckaert G (2000) Public management reform: a comparative analysis. Oxford University Press, Oxford

Preston L, Sapienza H (1990) Stakeholder management and corporate performance. J Behav Sci 19 (4):361-375

Provan K, Milward H (2001) Do networks really work? A framework for evaluating public-sector organizational networks. Publ Admin Rev 61(4):414-423

Radin BA, Coffee JN (1993) A critique of TQM: problems of implementation in the public sector. Public Adm Q 17:42-54

Rago W (1994) Adapting Total quality Management (TQM) to government: another point of view. Publ Admin Rev 54(1):61-64

Ribière V, LaSalle A, Khorramshahgol R, Gousty Y (1999) Hospital information systems quality: a customer satisfaction assessment tool. Proceedings of the 32nd Hawaii International Conference on System Sciences

Roch CH, Poister TH (2006) Citizens, accountability and service satisfaction-the influence of expectations. Urban Aff Rev 41(3):292-308

Roos I (1996) Customer switching behavior in retailing. Working Papers $n^{\circ} 327$, Swedish School of Economics and Business Administration, Helsinki, Finland

Roos I (1999) Switching paths in customer relationships. Doctoral Dissertation $n^{\circ} 78$, Helsinki: Swedish School of Economics and Business Administration, Finland

Roos I, Strandvik T (1996) Diagnosing the termination of customer relationships. Working Paper $\mathrm{n}^{\circ} 335$, Swedish School of Economics and Business Administration, Helsinki, Finland

Roy C, Seguin F (2000) The institutionalization of efficiency-oriented approaches for public service management. Public Prod Manage Rev 23(4):449-468

Rust RT, Oliver RL (1994) Service quality: insights and managerial implications from the frontier. In: Rust RT, Oliver RL (eds) Service quality: new directions in theory and practice. Sage Publications, London, pp 1-19

Schachter H (1995) Reinventing government or reinventing ourselves: two models for improving government performance. Publ Admin Rev 55(6):530-537

Schneider B, Bowen D (1985) Employee and customer perceptions of service in banks: replication and extension. J Appl Psychol 70(3):423-433

Schröder G, Birgelen M, Lemmink J, de Ruyter K, Wetzels M (2000) Moments of joy and sorrow-an empirical assessment of the complementary values of critical incidents in understanding customer service evaluations. Eur J Mark 34(1-2):107-125

Scitovsky I (1976) The joyless economy: an inquiry into human satisfaction and dissatisfaction. Oxford University Press, New York

Stauss B (1993) Using critical incident technique in measuring and managing service quality. In: Scheuing E, William F (eds) The service quality handbook. American Management Association, New York, pp 408-427

Stauss B, Hentschel B (1992) Attribute-based versus incident-based measurement of service quality: results of an empirical study with german car service industry. In: Kunst P, Lemmink J (eds) Quality management in service. Van Gorcum, Maastricht, pp 59-78

Stauss B, Weinlich B (1997) Process-oriented measurement of service quality. applying the sequential incident method. Eur J Mark 31(1):33-55 
Stocker G (1990) Reducing variability-key to continuous quality improvement. Manuf Syst 8-3:32-36 Stradling S, Anable J, Carreno M (2007) Performance, importance and user disgruntlement: a six-sep method for measuring satisfaction with travel modes. Transp Res Part A 41:98-106

Strandvik T, Liljander V (1994) Relationship strength in bank services. In: Jagdish N, Sheth A (eds) Proceedings from the 1994 Research Conference on Relationship Marketing: Theory, Methods and Applications, June 11-13, Atlanta, Georgia

Strauss A, Corbin J (1990) Basics of qualitative research. Sage Publications, London

Swan J, Rao C (1975) The critical incident technique: a flexible method for the identification of salient product attributes. J Acad Mark Sci 3:296-308

Swiss JE (1992) Adapting Total quality Management (TQM) to government. Publ Admin Rev 52(4):356362

Talbot C, Wiggan J, Hendy N, Rafferty A, Calcraft R, Freestone M, Wyatt B (2005) Jobcentre plus customer service performance and delivery: a qualitative review. Department for Work and Pensions, Research Report $n^{\circ} 276$, UK

Toonen T, Raadschelders J (1997) Public sector reform in Western Europe. Proceedings of the Conference on Comparative Civil Service Systems

Tse DK, Wilton PC (1988) Models of consumer satisfaction formation: an extension. J Mark Res 25:204212

Tsiros M, Mittal V (2000) Regret: a model of its antecedents and consequences in consumer decision making. J Consum Res 26(4):401-417

Van Ryzin G (2004) Expectations, performance and citizen satisfaction with urban services. J Policy Anal Manage 23(3):433-448

Vavra T (1997) Improving your measurement of customer satisfaction: a guide to creating, conducting, analyzing and reporting customer satisfaction measurement programs. ASQ Quality Press, Milwaukee

Vigoda-Gadot E (2000) Are you being served? The responsiveness of public administration to citizens' demands: an empirical examination en Israel. Public Adm 78(1):165-191

Walsh K (1991) Quality and public services. Public Adm 69:503-514

Westbrook R, Reilly M (1983) Value-percept disparity: an alternative to the disconfirmation of expectations theory of consumer satisfaction. Adv Consum Res 10:256-261

Wirtz J, Tomlin M (2000) Institutionalising customer-driven learning through fully integrated customer feedback systems. Managing Quality Service 10(4):205-215

Wright V (1994) Reshaping the state: the implications for public administration. West Eur Polit 17 (3):102-137

Yi Y (1990) A critical review of consumer satisfaction. In: Zeithaml V (ed) 1999, Review of marketing. American Marketing Association, Chicago, pp 68-123

Yin R (1994) Case study research: design and methods. Sage Publications, London

Zeithaml V, Berry L, Parasuraman A (1988) Communication and control processes in the delivery of service quality. J Mark 52:35-48

Zeithaml V, Parasuraman A, Berry L (1996) The behavioral consequences of service quality. J Mark $60: 31-46$

Zhao X, Bai C, Hui Y (2002) An empirical assessment and application of servqual in a mainland Chinese department store. Total Qual Manag 13(2):241-254 